\title{
Are Traditionally Used Resources within Conservation Areas a Function of Their Sizes?
}

\author{
Thokozani Simelane
}

Centre for African Ecology, Nelson Mandela University and South African National Parks, Port Elizabeth, South Africa

E-mail: tsimelane@ai.org.za

Received April 13 $3^{\text {th }}, 2011$; revised May $9^{\text {th }}, 2011$; accepted May $18^{\text {th }}, 2011$.

\begin{abstract}
A perception that there is a proportional relationship between the size of a conservation area and the occurrence or abundance of resources available was tested in this paper. This was done by evaluating the occurrence (from records of plant and animal species) of traditionally used biological resources from four national parks of South Africa that have different sizes. Results obtained show that contrary to a general belief that bigger conservation areas might have higher proportions and possibly abundance of traditionally used resources, this is not true. In addition, results reflected that the occurrence of traditionally used biological resources within the conservation areas is not a function (in terms of the size) of their sizes. Drawing this relationship has put forth a question of whether there is a direct relationship between the biodiversity of conservation estates and the resources available. While this study did not attempt to provide an absolute answer to this question, it has laid a foundation to tackle it further. Providing answers to questions like these will not only increase the ecological value of conservation areas among traditional societies but will also help to align conservation estates with TRIPS (trade related aspects of intellectual property) and other international instruments like CBD (Convention on biodiversity). All which call for inclusive approach to the management of natural resources and biodiversity.
\end{abstract}

Keywords: Conservation, Traditionally Used Resources, Conservation Areas, National Parks, Biodiversity

\section{Introduction}

In addition to their primary functions of conserving biodiversity and fragile ecosystems, conservation areas are known to promote the protection of different species of plants and animals that are used as traditional resources (e.g. traditional medicines). These are referred to as traditionally use biological resources [1-3]. To date more than 3000 plant species are known to be used as traditional medicines. These include not less than 350 species that are freely traded on streets and herbalists' shops $[3,4]$. Approximately 20000 tons of these plants species are harvested annually for trading as traditional medicines $[5,6]$. Trading with these plants provides income for some communities $[5,7]$ and it is estimated that not less than \$ 90 million is generated annually [7-11].

Considering the conservation statuses of most of these plant species [12], their presence in conservation areas demonstrates a critical role that is played by conservation areas in conserving and preserving a component of biodiversity that is used as traditional resources. Their existence within conservation areas can further be considered as representing a portion of biodiversity that is better understood and recognized by traditional societies $[13,14]$.

As the case with plant species, more than 280 vertebrates species are known to be used and sold for traditional and cultural purposes [15]. These include 171 mammals, 58 birds, 31 reptiles and various marine organisms [15]. A larger proportion of these species, some with critical conservation status (e.g. Panthera pardus and Erinaceus frontalis), are also freely available for sale in street markets and herbalists' shops [15]. This happens in spite of heightened efforts by conservation agencies to conserve them.

Of all animal groups that are traded in the markets, mammals constitute the highest proportion (about $61 \%$ ), with more than 150 species being found in herbalist shops $[16,17]$. Of critical note is that thirty one percent of these species are listed in Red Data Books [8,18-20]. The general tendency is that species with critical conservation status are in high demand and are thus highly priced $[21,22]$. This could be one of the causes of the reduction (in numbers) of these species outside conservation areas 
$[17,23,24$,$] . In this context, the role of conservation areas$ in protecting these species is quite critical. With additional effects of climate change, habitat destruction, hunting [25], road kills, illegal poaching, poisoning and deaths through natural diseases, it is obvious that the future existence, outside conservation areas, of most animals that are used as traditional resources cannot be guaranteed [23,26,27].

As numbers of traditionally used resources continue to decline outside conservation areas, there is a growing perception that these resources are in abundant within the borders of conservation areas. This perception is somehow a major cause for conflict between conservation authorities and communities around conservation areas, who demand access to these resources.

In addition to this, there also exist a perception that larger conservation areas are rich in traditionally used resources, both in terms of diversity and abundance. In the existence of this perception, this analysis was conducted with the aim of determining the availability of these resources in relation to the size and biodiversity of the parks. The study analyzed four national parks of South Africa (i.e. Addo Elephant National Park (AENP), Golden Gate Highlands National Park (GGHNP), Mountain Zebra National Park (MZNP) and Karoo National Park (KRNP)). In the face of changing conservation philosophies and the stance of conservation authorities on biodiversity and its management through community support [12], the presence of traditionally used biological resources within conservation areas represent a buffer between western based conservation approaches and traditional methods of managing and conserving biodiversity $[28,29]$. This analysis considered that highlighting the role of conservation areas in protecting a component of biodiversity that is used as traditional resources could increase the awareness of the importance of conserving of biodiversity by users of these resources and thus enhance the value of conservation of biodiversity among all communities. The study tested the hypotheses that:

a) conservation areas are rich in plant and animal species used as traditional resources,

b) these resources are a function of the number of species available in a conservation areas,

c) their presence within the conservation area differ in the proportion of plant and animal species available,

d) they tend to have critical conservation statuses and

e) their proportions within conservation areas vary between taxa and the size of the conservation area.

Many years ago, Siegfried [30] made a significant comment on the lack of reliable comprehensive biodiversity records and analysis for conservation areas. Since this comment, considerable efforts were made to address this issue, particularly for national parks. This resulted into a number of publications and establishment of data bases on records of plants (especially within the national parks of South Africa) (KSANP Data Base 1985-1998; van Wyk [31], Du Preez \& Bezuidenhout [32], Pond [33], Botha [34] available within conservation areas. With a combined impetus of these efforts and investments made on determining values of biodiversity to human development, additional importance and meaning of biodiversity to various communities (including traditional societies) have also been determined and defining biodiversity through values provided by all societies (inclusive of traditional societies) has become critical.

\section{Research Methods}

Existing records such as Liversidge [35], Roberts [36], Bates [37], Earlè \& Lawson [38], Bezuidenhout [39,40], Johnson [41], Williams [42] and checklists such as van Wyk [31], Zietsman [43] as well as unpublished data of plants (KSANP ${ }^{1}$ Data Base 1985-1998) and animals Knight \& Hall-Martin [44], Castley \& Knight [45] that occur within four national parks of South Africa (AENP, MZNP, KRNP and GGHNP) were used in this study, to compile lists of traditionally used plant and animal species available. In addition data bases such as PRECIS, SARARES and MEDBASE were inspected for additional information (http://www.nbi.ac.za/information/databases. $\mathrm{htm}$ ) on traditional uses of various species. Additional information about traditional and cultural uses of identified species was obtained from the published literature [1,34,46-55] traditional healers, street vendors and communities around the studied national parks. In determining the possible impacts of traditional uses of identified plants and animals species conservation statuses of identified species were determined using the Red Data Books: Smithers [18] for mammals, Branch [56] for reptiles, Hilton-Taylor [57] for plants and Barnes [58] for birds.

\subsection{Statistical Analyses}

The number of plant and animal species recorded in each park was correlated to the number of available traditionally used plant and animal species, through a Spearman's correlation analysis [59]. This tested the hypothesis that traditionally used resources available in a park could be the function of the number of species available and size of the park; thereby investigating the possibility that more diverse conservation areas may have higher proportions of traditionally used resources.

The differences in the availability of traditionally used resources between the parks were compared statistically through a Chi-squared $\left(\chi^{2}\right)$ analysis [59]. This tested the hypothesis that parks differ in the proportions of plant and

\footnotetext{
${ }^{1}$ Kimberley South African National Parks Herbarium
} 
animal species used as traditional resources. Differences in the proportions of plant and animal species used as traditional resources in each park and the proportions of plant and animal species not used were again compared statistically, using a Chi-squared analysis. Differences between the used and threatened proportions of plant and animal species (as indicated by being listed in Red Data Books) and those listed but not used were also compared statistically using a Chi-Squared analysis [59]. This tested the hypothesis that plants and animals used as traditional resources tend to have threatened conservation statuses. In addition, differences between the taxa of vertebrate species recorded as used for different traditional purposes were compared using a Chi-squared analysis. This tested the hypothesis that proportions of species used as traditional resources in conservation areas vary between the taxa.

\section{Results}

\subsection{Plant Species Used as Traditional Resources}

A total of 1463 plant species were recorded as occurring within the four studied national parks. Six hundred and twenty five of these species (42.7\%) occurred in AENP, 479 (32.7\%) in MZNP, 124 (8.5\%) in GGHNP and 235 $(16.1 \%)$ in KRNP (Table 1). One hundred and seventy three of these species $(9.5 \%)$ were found to be used for different traditional purposes, with MZNP (30\%) having higher proportions of traditionally used plant species than the three other parks (AENP, GGHNP and KRNP) (Table 1). The occurrence of traditionally-used plant species (in the parks) was positively correlated $(r=0.43, d f=4, p$ $<0.05$ ) to the total number of species available within each park.

Eighty five percent (124) of the identified traditional resource plant species were mainly used as traditional medicines and $17 \%$ for non-medicinal uses. The non- medicinal uses included food (17 species), tools (10 species) and building material ( 7 species). Fruits and berries of some species were identified as being eaten, with some being particularly important as a dietary supplement during times of famine. Roots, bulbs and tubers served as starch supplements and leaves of certain species (mostly herbs) as vegetables. Parts targeted for medicinal uses varied and ranged from the whole plant (for herbs and geophytes) to roots, leaves and fruits.

While the chemical content of the plant species is considered to be the main determinant of most species used in traditional medicine [60], the use of other species emerged to be largely due to their association with traditional beliefs. Of note Celtis africana, whose wood is believed to provide protection against the bad intentions of sorcerers, Kigelia africana, whose fruit if hung in the hut is believed to provide protection against whirlwinds and Halleria lucida, which is believed to provide protection against evil spirits.

Although the recorded traditionally used plant species are largely harvested for sale or used by individual traditional healers, five of these (Table 2) were found to be already commercially exploited with Pelargonium sidoides and Harpagophytum procumbens considered to have potential for international commercialization [3]. In this regard, Harpagophytum procumbens is regarded as a medicinal plant of international importance that is being successfully propagated on a limited commercial scale [3].

Only four $(2.2 \%)$ of the recorded traditionally used plant species were listed in Red Data Book [57]; as rare (Crassula arborescens), vulnerable (Kniphofia rooperi) and not threatened (Cotyledon orbiculata, Nemesia fruticans). Three of these species are also listed as endemic (i.e. Kniphofia rooperi, Cotyledon orbiculata and Crassula arborescens) to South Africa. Listed species oc-

Table 1. Number of plant species identified as used for traditional purposes (AENP = Addo Elephant National Park, MZNP = Mountain Zebra National Park, GGHNP = Golden Gate Highlands National Park, KRNP = Karroo National Park).

\begin{tabular}{|c|c|c|c|c|c|c|c|c|}
\hline \multirow{3}{*}{ Park } & \multicolumn{3}{|c|}{ Plant species recorded in the park } & \multicolumn{5}{|c|}{ Plant species identified as used for traditional purposes } \\
\hline & \multirow{2}{*}{ Families } & \multirow{2}{*}{ Species } & \multirow{2}{*}{$\begin{array}{l}\% \text { representation of plant } \\
\text { species recorded in SA }\end{array}$} & \multirow{2}{*}{ Families } & \multicolumn{2}{|c|}{ Species used } & \multicolumn{2}{|c|}{ Species not used } \\
\hline & & & & & $\mathbf{n}$ & $\%$ & $\mathbf{n}$ & $\%$ \\
\hline AENP & 73 & 625 & $2.7 \%$ & 27 & 43 & 6.8 & 582 & 93.2 \\
\hline MZNP & 82 & 479 & $2.1 \%$ & 30 & 53 & 11.0 & 426 & 89.0 \\
\hline GGHNP & 46 & 124 & $0.5 \%$ & 26 & 37 & 29.8 & 87 & 70.2 \\
\hline KRNP & 56 & 235 & $1.0 \%$ & 27 & 23 & 9.8 & 212 & 90.2 \\
\hline Total & 322 & 1785 & $7.8 \%$ & 143 & 211 & 14.9 & 1574 & 85.1 \\
\hline
\end{tabular}


Table 2. Commercially Exploited Traditionally Used Plants (AENP = Addo Elephant National Park, MZNP = Mountain Zebra National Park).

\begin{tabular}{|c|c|c|c|}
\hline Family & $\begin{array}{l}\text { Common and } \\
\text { species names }\end{array}$ & $\begin{array}{c}\text { Park } \\
\text { where it } \\
\text { occurs }\end{array}$ & Use \\
\hline Asteraceae & $\begin{array}{l}\text { Chicory } \\
\text { (Cichorium } \\
\text { intybus). }\end{array}$ & AENP & $\begin{array}{l}\text { Roots are processed into a com- } \\
\text { mercial product known as chic- } \\
\text { ory, which is sold as a coffee } \\
\text { additive or coffee substitute. } \\
\text { The root has tonic, sedative and } \\
\text { mild laxative activities (van } \\
\text { Wyk, Oudtshoorn \& Gericke } \\
\text { 1997). }\end{array}$ \\
\hline Sapindaceae & $\begin{array}{l}\text { Jacket plum } \\
\text { (Pappea cap- } \\
\text { ensis) }\end{array}$ & AENP & $\begin{array}{l}\text { Fruit used for jelly and edible } \\
\text { seed oil used to make soap (van } \\
\text { Wyk, Oudtshoorn \& Gericke } \\
\text { 1997). }\end{array}$ \\
\hline $\begin{array}{l}\text { Aspho- } \\
\text { delaceae }\end{array}$ & $\begin{array}{l}\text { Bitter aloe } \\
\text { Aloe ferox }\end{array}$ & $\begin{array}{l}\text { AENP } \\
\text { and } \\
\text { MZNP }\end{array}$ & $\begin{array}{l}\text { Leaf exudates used as laxative } \\
\text { medicine. Also used in self-care } \\
\text { remedies such as "lewenses- } \\
\text { sens", and "Schweden bitters" } \\
\text { (van Wyk, Oudtshoorn \& Ge- } \\
\text { ricke 1996). }\end{array}$ \\
\hline Geraniaceae & $\begin{array}{l}\text { Rabas (Pelar- } \\
\text { gonium si- } \\
\text { doides }\end{array}$ & AENP & $\begin{array}{l}\text { Used as an ingredient for } \\
\text { "Umckaloabo", a German me- } \\
\text { dicinal remedy used to treat } \\
\text { bronchitis in children (van Wyk, } \\
\text { Oudtshoorn \& Gericke 1997). }\end{array}$ \\
\hline
\end{tabular}

curred in AENP (Crassula arborescens), KRNP (Cotyledon orbiculata) and MZNP (Kniphofia rooperi). One of the endemic, rare species (Crassula arborescens) is listed as internationally threatened. There were significantly fewer $\left(\chi^{2}=0.83, d f=4, p<0.05\right)$ used listed species than the listed, not-used species. There was no statistically significant ( $\chi^{2}=5, d f=4, p>0.05$ ) differ- ence between the parks with regard to the occurrence of the threatened, used species. However, GGHNP recorded a comparatively high proportion (2.3\%) of listed, not-used species (Table 3).

\subsection{Animal Species Used as Traditional Re- sources}

One hundred and twelve species of vertebrates that occurred within the studied national parks were identified as being used for different traditional and cultural purposes (Table 4). The traditional uses of the identified vertebrate species included meat for consumption, traditional attire, decoration of traditional healer's consulting rooms and traditional medicines. Species used in traditional medicines either served as ingredients additional to medicinal plants or were used without being mixed. Mammals (60 species) had the highest proportion (53.6\%) of species used, followed by birds (27 species $(24 \%)$ ) and reptiles (23 species $(20.5 \%)$ ). While birds and mammals were used for various traditional purposes that include meat, attire and treating different illnesses, the highest proportion $(67 \%)$ of reptiles was specifically used for traditional medicinal purposes.

As in the case of the plant species, some animal species were associated with traditional beliefs. Notable among these were bird species such as ground hornbill (Bucorvus leadbeateri), which is believed to possess powers of causing a thunderstorm and the hamerkop (Scopus umbretta), which was widely associated with witchcraft, and all species of owls, which were regarded as the birds of ill omen and witcheraft.

Unlike plant species, which were used for diseases that

Table 3. Total numbers of traditionally used plant species from four studied national parks.

\begin{tabular}{|c|c|c|c|c|c|c|}
\hline \multirow[b]{2}{*}{ Parks } & \multirow[b]{2}{*}{$\begin{array}{l}\text { Total number of } \\
\text { species occurring } \\
\text { in the park }\end{array}$} & \multicolumn{2}{|c|}{ Plant species not used } & \multicolumn{3}{|c|}{ Plant species used } \\
\hline & & $\begin{array}{c}\text { Number of species } \\
\text { not used but listed } \\
\text { in SA red data } \\
\text { book }\end{array}$ & $\begin{array}{c}\text { Number of species } \\
\text { not used and not } \\
\text { listed in red data } \\
\text { book }\end{array}$ & $\begin{array}{l}\text { Number of species } \\
\text { used }\end{array}$ & $\begin{array}{l}\text { Number of species } \\
\text { used and listed in } \\
\text { SA red data book }\end{array}$ & $\begin{array}{c}\text { Number of species } \\
\text { used but not listed } \\
\text { in SA red data } \\
\text { book }\end{array}$ \\
\hline AENP & 625 & $5(0.85 \%)$ & $577(92.3 \%)$ & 43 & $1(0.2 \%)$ & $42(24.3 \%)$ \\
\hline MZNP & 479 & $8(1.9 \%)$ & $471(98.3 \%)$ & 53 & $1(0.2 \%)$ & $52(30.0 \%)$ \\
\hline GGHNP & 124 & $2(2.32 \%)$ & $122(98.4 \%)$ & 37 & $0(0.0 \%)$ & $37(22 \%)$ \\
\hline KRNP & 235 & $3(1.4 \%)$ & $232(98.0 \%)$ & 23 & $1(0.5 \%)$ & $22(12.3 \%)$ \\
\hline Total & 1785 & 22 & 1720 & 211 & 4 & 211 \\
\hline
\end{tabular}

The table also shows total numbers of species listed in South Africa's red data books (following Hilton-Taylor 1996). Numbers in brackets reflect the percentages of listed species in each park. 
Table 4. Vertebrate species from the four analyzed National Parks, which were identified as used in traditional cultural practices and medicinal purposes.

\begin{tabular}{|c|c|c|c|c|c|c|}
\hline Park & Taxon & $\begin{array}{c}\text { Total No of species } \\
\text { recorded in the } \\
\text { park }\end{array}$ & $\begin{array}{l}\text { \% Representation of the } \\
\text { total number of species } \\
\text { known to occur in South } \\
\text { Africa }\end{array}$ & $\begin{array}{l}\text { No of species used } \\
\text { for traditional and } \\
\text { cultural purposes } \\
\text { (with \% of total } \\
\text { species in the } \\
\text { park) }\end{array}$ & $\begin{array}{l}\text { No of species not } \\
\text { used (with \% of } \\
\text { total species in } \\
\text { the park) }\end{array}$ & $\begin{array}{c}\chi^{2} \text { value for test- } \\
\text { ing the difference } \\
\text { between used and } \\
\text { not used species } \\
\mathbf{P}<\mathbf{0 . 0 0 1}\end{array}$ \\
\hline \multirow{4}{*}{ AENP } & Mammals & 92 & 37.2 & $31(33.7 \%)$ & $61(66.3 \%)$ & \multirow{4}{*}{$26.4^{* *}$} \\
\hline & Birds & 318 & 41.0 & $18(5.7 \%)$ & $300(94.3 \%)$ & \\
\hline & Reptiles & 49 & 16.4 & $8(16.3 \%)$ & $41(83.7 \%)$ & \\
\hline & Total & 459 & & 57 & 402 & \\
\hline \multirow{4}{*}{ MZNP } & Mammals & 79 & 32.0 & $36(45.6 \%)$ & $43(55.4 \%)$ & \multirow{4}{*}{$38.6 * *$} \\
\hline & Birds & 265 & 34.2 & $19(7.2 \%)$ & $246(92.8 \%)$ & \\
\hline & Reptiles & 53 & 17.7 & $20(37.7 \%)$ & $33(62.3 \%)$ & \\
\hline & Total & 397 & & 75 & 322 & \\
\hline \multirow{4}{*}{ GGHNP } & Mammals & 79 & 32.0 & $36(45.6 \%)$ & $43(55.4 \%)$ & \multirow{4}{*}{$60.5 * *$} \\
\hline & Birds & 255 & 33.0 & $15(5.9 \%)$ & $240(94.1 \%)$ & \\
\hline & Reptiles & 35 & 11.7 & $3(8.6 \%)$ & $32(91.4 \%)$ & \\
\hline & Total & 369 & & 54 & 315 & \\
\hline \multirow{4}{*}{ KRNP } & Mammals & 77 & 31.2 & $36(46.8 \%)$ & $41(53.2 \%)$ & \multirow{4}{*}{$40.8 * *$} \\
\hline & Birds & 226 & 29.2 & $15(6.6 \%)$ & $211(93.4 \%)$ & \\
\hline & Reptiles & 67 & 22.4 & $19(28.4 \%)$ & $48(71.6 \%)$ & \\
\hline & Total & 370 & & 70 & 300 & \\
\hline
\end{tabular}

are well defined in scientific terms, animal species were also used in traditional medicines for disease and illnesses that are difficult to define. Some of these illnesses include izitshopi, imeqo, ukwethuka and inyoni, which are extensively described by Ngubane [54] as being caused by stepping over the tracks of certain animal species (snakes) or through spells cast by witchdoctors using some animal species (owls) as their agents. The use of animals to cure these illnesses reflects the general interpretation of the causes of illnesses by traditional healers. This perception normally determines the inclusion of animal species in potions used to cure the perceived illness and does not rely on a pharmacological action.

Twenty (18\%) traditionally-used vertebrate species are considered threatened $[18,56,58]$. These include $14(70 \%)$ mammals (listed as rare (6), indeterminate (2), endangered (2), not designated (1) and vulnerable $(4,28.5 \%)$ ) and six birds (listed as rare (1), vulnerable (2) and require monitoring (3)) (Table 5). In all parks, mammals comprised of a significantly $\left(\chi^{2}=3.7, d f=3, p<0.001\right)$ higher proportion of the listed used species (Table 5).

\subsection{Relationship between Identified Resources and the Size of the Park}

While it was expected that the occurrence of traditionally used resources within the parks would be directly correlated to the size of the park (Table 6), the occurrence of these resources within the parks was found not to differ between the parks ( $\left.\chi^{2}=168.0, d f=156, p>0.05\right)$, indicating that all five studied parks had similar proportions of traditionally used resources.

\section{Discussion}

What has emerged from this analysis is that while most earlier studies on traditional resources $[1,34,42,49,60-62]$

Table 5. Conservation status of animal species recorded as used for different traditional purposes.

\begin{tabular}{|c|c|c|c|c|c|}
\hline \multirow{2}{*}{ Parks } & \multirow{2}{*}{ Taxon } & \multicolumn{2}{|c|}{ Animal species used } & \multicolumn{2}{|c|}{ Animal species not } \\
\hline & & Threatened & $\begin{array}{l}\text { Not threat- } \\
\text { ened }\end{array}$ & Threatened & $\begin{array}{c}\text { Not } \\
\text { threatened }\end{array}$ \\
\hline \multirow{4}{*}{ AENP } & Mammals & $4(15.4 \%)$ & $22(84.6 \%)$ & $10(15.2 \%)$ & $56(84.8 \%)$ \\
\hline & Birds & $3(9.1 \%)$ & $19(90.9 \%)$ & $21(7.1 \%)$ & $\begin{array}{c}275 \\
(92.9 \%)\end{array}$ \\
\hline & Reptiles & $0(0.0 \%)$ & $18(100 \%)$ & $1(3.2 \%)$ & $30(96.8 \%)$ \\
\hline & Total & 7 & 59 & 32 & 361 \\
\hline \multirow{4}{*}{ MZNP } & Mammals & $3(8.3 \%)$ & $33(91.7 \%)$ & $7(16.3 \%)$ & $36(83.7 \%)$ \\
\hline & Birds & $3(15.8 \%)$ & $16(84.2 \%)$ & $17(6.9 \%)$ & $\begin{array}{c}229 \\
(93.1 \%)\end{array}$ \\
\hline & Reptiles & $0(0.0 \%)$ & $21(100 \%)$ & $1(3.2 \%)$ & $31(96.8 \%)$ \\
\hline & Total & 6 & 70 & 25 & 296 \\
\hline \multirow{4}{*}{ GGHNP } & Mammals & $5(13.9 \%)$ & $31(86.1 \%)$ & $6(14.0 \%)$ & $37(86.0 \%)$ \\
\hline & Birds & $3(15.0 \%)$ & $17(85.5 \%)$ & $20(8.5 \%)$ & $\begin{array}{c}215 \\
(91.5 \%)\end{array}$ \\
\hline & Reptiles & $0(0.0 \%)$ & $13(100 \%)$ & $0(0.0 \%)$ & $22(100 \%)$ \\
\hline & Total & 8 & 61 & 26 & 274 \\
\hline \multirow{4}{*}{ KRNP } & Mammals & $4(11.4 \%)$ & $31(88.6 \%)$ & $6(14.2 \%)$ & $36(85.8 \%)$ \\
\hline & Birds & $2(11.8 \%)$ & $15(88.2 \%)$ & $15(7.2 \%)$ & $\begin{array}{c}194 \\
(92.8 \%)\end{array}$ \\
\hline & Reptiles & $0(0.0 \%)$ & $15(100 \%)$ & $0(0.0 \%)$ & $52(100 \%)$ \\
\hline & Total & 6 & 61 & 21 & 282 \\
\hline
\end{tabular}

Threatened conservation status indicated by being listed in the Red Data Books, Smithers [18] for mammals, Branch [19] for reptiles and Barnes [58] for birds. 
concentrated on listing the presence of traditionally used plants or animals within conservation areas, investigating the occurrence of these resources in relation to their conservation statuses and sizes of conservation areas should be considered and used as a new approach of defining the biological wealth of conservation areas.

Contrary to a perception that conservation areas are rich in traditionally used biological resources [63], this analysis has demonstrated that the occurrence of these resources within the conservation areas is of limited extent, with traditionally used plants being less well represented than the traditionally used animals (Table 3 and 4).

The analysis further demonstrated that the traditionally used species within conservation areas is a function of the number of species available within the conservation estates but not the size of the estate. Thus, conserved areas with large number of plants or animal species can be regarded as having higher proportions of traditionally used biological resources but this may not be linked to the sizes of a conservation area. Through this study it also emerged that the numbers of traditionally used resources differ among the conservation areas. This heterogeneous occurrence of these resources within the conservation areas reflects that not all conservation areas can be regarded as being rich in traditionally-used biological resources. This thus calls for the identification of conservation areas that can be regarded as rich in traditionallyused resources. Similar studies on species abundance and endemism as well as biodiversity richness has helped to draw to the attention of conservation agencies, areas that require conservation priority and this has led to the mapping and increased conservation efforts of biodiversity hotspots of the world [64-68].

The emergence of these facts draws to our attention a need to investigate if traditionally used resources are a function of the biodiversity of conservation areas. This requires the development of an index that will link the biodiversity of conservation areas with traditional resources present within the conservation estates. Such an index will be an important tool that can be used in assessing conservation areas according to traditional values, resources and perceptions provided by local communities. This is also of great significance as most conservation areas were solely established with the purpose of protecting plant or animal species identified to have critical conservation statuses (Table 6). With the new view of assessing conservation areas according to attached traditional values $[13,67]$ and their contribution to biodiversity management can help bridge the gap that exists between current conservation objectives and expectations of the societies residing around the conservation areas [68].
Table 6. Park sizes, objectives and their resources (biodiversity).

\begin{tabular}{|c|c|c|c|}
\hline $\begin{array}{c}\text { Park } \\
\text { Name }\end{array}$ & Size & Park objectives & Biodiversity \\
\hline AENP & $139000 \mathrm{ha}$ & $\begin{array}{l}\text { The park was pro- } \\
\text { claimed so as to con- } \\
\text { serve a viable popula- } \\
\text { tion of Addo Elephants } \\
\text { (Loxodonta Africana), } \\
\text { African buffalo (Synce- } \\
\text { rus caffer) and black } \\
\text { rhinoceros (Diceros } \\
\text { bicornis). }\end{array}$ & $\begin{array}{l}\text { The park hosts repre- } \\
\text { sentatives of four of } \\
\text { South Africa's seven } \\
\text { terrestrial biomes i.e. } \\
\text { Nama karoo, Fynbos, } \\
\text { forest and thicket. }\end{array}$ \\
\hline MZNP & 18 994ha & $\begin{array}{l}\text { The park was pro- } \\
\text { claimed with the aim of } \\
\text { saving the Cape Moun- } \\
\text { tain Zebra (Equus zebra } \\
\text { zebra) from extinction. } \\
\text { Its additional aim is to } \\
\text { preserve the karoo } \\
\text { vegetation that is suit- } \\
\text { able for the conserva- } \\
\text { tion of Cape Mountain } \\
\text { Zebras. }\end{array}$ & $\begin{array}{l}\text { The vegetation of the } \\
\text { park is dominated by } \\
\text { an abundance of } \\
\text { grasses and dwarf } \\
\text { shrubs-classified as } \\
\text { the Eastern Mixed } \\
\text { Karoo. }\end{array}$ \\
\hline GGHNP & 11 630ha & $\begin{array}{l}\text { The park was pro- } \\
\text { claimed so as to con- } \\
\text { serve a representative } \\
\text { part of the spectacular } \\
\text { Clarens Sandstone for- } \\
\text { mation. It also aims to } \\
\text { conserve the highland } \\
\text { sourveld at the upper } \\
\text { reaches of the catchment } \\
\text { area of Klein Caledon } \\
\text { River. }\end{array}$ & $\begin{array}{l}\text { The vegetation in the } \\
\text { park can be divided } \\
\text { into grassland and } \\
\text { woodland/forest. Vir- } \\
\text { tually, the entire park } \\
\text { carries grassland vege- } \\
\text { tation. }\end{array}$ \\
\hline KRNP & 69 624ha & $\begin{array}{l}\text { The park was pro- } \\
\text { claimed so as to con- } \\
\text { serve the Karoo flora } \\
\text { and to protect a repre- } \\
\text { sentative example of } \\
\text { this vegetation against } \\
\text { further degradation and } \\
\text { exploitation. }\end{array}$ & $\begin{array}{l}\text { Variations in altitude } \\
\text { have resulted to a park } \\
\text { to have a distinct con- } \\
\text { trast between the } \\
\text { vegetation of upper } \\
\text { and the lower plateau. } \\
\text { The upper. }\end{array}$ \\
\hline
\end{tabular}

Overall, the presence of traditional resources within the conservation areas provides various advantages for conservation $[13,68-70]$. They provide opportunities for the extension of conservation awareness among communities [71]. They offer opportunities of implementing philosophies of community-based natural resource management [72]. Contrary to previous law enforcement management methods of managing these resources, participation of communities in managing traditionally used biological resources will improve the relationships between conservation authorities and communities [73] as cooperative management broadens the understanding of conservation objectives by communities and increases their understanding of the role played by conservation areas in conserving natural resources and biodiversity [74].

Although traditional used biological resources appear to occur in limited proportions within the conservation areas (Table 3 and 4), their abundance within conserva- 
tion areas is generally comparatively higher than neighbouring unprotected land [75]. This effect is particularly strongly developed for larger animals, which do not persist outside of conservation areas, such as elephant, leopard and lions [76]. Thus their presence within conservation areas offers them protection. For instance, the occurrence of some traditionally used plants that have critical conservation statuses within some parks reflected the significant role played by these parks in protecting threatened resources [69]. In spite of this, what can be said is that each conserved area supports the conservation of a distinctive proportion of traditionally-used plant and animal species (Table 3 and 4), which may be threatened outside conservation areas not only by overexploitation but also by different forms of land use like development, agriculture or persecution due to beliefs or stigmas associated with them [22].

Of critical note is that while this analysis provides a broad picture about the occurrence of traditional resources within conservation areas and relates them to their conservation statuses, it does not estimate the abundance or dynamics of these resources within the conservation areas-important indicators of sustainability. This thus implies the necessity of supplementing this study with the investigation of the abundance and dynamics of the identified traditional resources within the national parks. Such studies should provide guidelines of harvesting traditionally used resources within the conservation areas. It must also provide strategies of forging collaborative management.

Organizations like TRAFFIC have already started with collaborative management of traditionally used natural resources, working directly with the people whose livelihoods depend on these resources [27]. This has set the stage for partnerships between the conservation agencies and communities, where both parties strive to ensure the sustainable supplies of valued resources for the future generations [27]. Benefits of co-operative management of natural resources are manifold $[77,78]$. As conservation areas struggle to incorporate local communities into their management, participation of communities in designing control measures and policies of resources they associate with will increase self-sufficiency among communities and this will increase chances of developing the social support of conservation of biodiversity.

Although most traditionally-used biological resources do not feature prominently in Red Data Books (Table 3 and 5), most of these resources are already threatened outside conservation areas $[3,72]$ due to various threats that include over-harvesting and unsustainable forms of land use. This is obvious with traditionally used animals $[8,24]$. Animal species like the leopard, spotted genet and many other species used for traditional attire and medi- cine are now largely confined within the boundaries of the conservation areas [72]. Those that still occur outside conservation areas are limited in distribution and their future persistence is uncertain $[18,79]$. Therefore, this study reflects a need to re-assess the Red Data Book statuses of traditionally used species to increase their conservation efforts. In the meantime, conservation areas need to prioritize the conservation of all traditional resources, and improve their protection by developing effective management programmes that will ensure their protection while developing relationships between conservation areas and local communities. However, to sustain the collaborative management of these resources in conservation areas, there is a need to: 1) develop inventories of the available traditionally used biological resources within conservation areas and those that are available outside conservation areas that are used by communities; 2) educate communities about the contribution of conservation areas towards the conservation of traditionally used biological resources and development opportunities associated with conservation of natural resources; 3 ) improve the participation of local communities in the management of these resources through projects that may enhance the communities' conservation awareness and 4) devise strategies that would promote the sustainable harvesting of the required resources [80,81].

\section{REFERENCES}

[1] J. M. Watt and M. G. Breyer-Brandwijk, "The Medicinal and Poisonous Plants of Southern and Eastern Africa," Livingstone, London, 1962.

[2] F. W. Fox and N. Young, "Food from the Veld," Delta, Johannesburg, 1982.

[3] B. Van Wyk, B. Oudsthoorn and N. Gericke, "Medicinal Plants of South Africa," Briza publications, Pretoria, 1997.

[4] A. B. Cunnigham, "Imithi Isizulu: The Traditional Medicine Trade in Kwazulu-Natal," Master of Social Science dissertation, University of Natal, Pietermaritzburg, 1992.

[5] R. Scott-Shaw, "A Directory of Medicinal Plants Trade in Natal with Zulu Names and Conservation Status," Natal Parks Board internal Report, Natal Parks Board, 1990.

[6] M. Mander, "Marketing of indigenous medicinal plants in South Africa: A case study in Kwazulu-Natal," Rome-Food and Agriculture Organization of the United Nations, 1998.

[7] L. V. Williams, "The Witwatersrand Muti Trade," Veld \& Flora, March 1996, pp. 12-14.

[8] A. B. Cunningham, "An Investigation of the Herbal Medicine Trade in KwaZulu," Investigational Re- 
port No.29, Institute of Natural Resources, University of Natal, Pietermaritzburg, 1988.

[9] A. B. Cunningham, "Income, Sap Yield and Effects of Sap Tapping on Palms in the South-Eastern Africa," South African Journal of Botany, Vol. 56, No. 2, 1990, pp. 137-144.

[10] A. B. Cunningham and A. S. Zondi, "Striped Weasel: Traditional Medicine and Conservation," Endangered Wildlife, Vol. 11, 1992, pp. 10-15.

[11] S. A. McCartan and J. van Staden, "MicropropaGation of Members of the Hyacinthaceae with Medicinal and Ornamental Potential," South African Journal of Botany, Vol. 65, No.5-6, 1999, pp. 361-369.

[12] T. S. Simelane, "Role of Conservation Areas in Conserving Traditionally Used Natural Resources and Biodiversity," Ph.D. thesis. Nelson Mandela Metropolitan University, Port Elizabeth, 2005.

[13] J. Botha, "Perceptions of Availability and Values of Medicinal Plants Traded in Areas Adjacent to the Kruger National Park," MSc thesis dissertation, University of the Witwatersrand, Johannesburg, 2001.

[14] A. B. Cunningham, "Indigenous Plant Use: Balancing Human Needs and Resources," B. J. Huntley (ed.) "Biotic Diversity in Southern Africa: Concepts and Conservation," Oxford University Press, Cape Town, 1989.

[15] T. S. Simelane, "The Traditional Use of Indigenous Vertebrates," MSc Dissertation, University of Port Elizabeth, Port Elizabeth, 1996.

[16] A. B. Cunningham and A. S. Zondi, "Use of Animal Plants for Commercial Trade in Traditional Medicine," Institute of Natural Resources, Report 76, 1991, pp. 1-40.

[17] T. S. Simelane and G. I. H. Kerley, "The Conservation Implications of the Use of Indigenous Vertebrates by Traditional Healers: With Reference to Xhosa Traditional Healers," South African Journal of Wildlife Research, Vol. 28, 1998, pp. 121-126.

[18] R. H. N. Smithers, "South African Red Data Book-Terrestrial Mammals," South African National Scientific Programme Report No.125, FRD \& CSIR, Pretoria, 1986.

[19] W. R. Branch, "South African Red Data Book: Reptiles and amphibians," South African Scientific programme, Report 151, 1988, pp. 1-24.

[20] J. Hilton-Taylor, E. T. F. Witkowski and C. M. Shackleton, "An inventory of medical plants traded on the western boundary of the Kruger National Park, South Africa," Koedoe, Vol. 44, No. 2, 2001, pp. 7-46.
[21] A. B. Cunningham and A. S. Zondi, "Striped Weasel: Traditional Medicine and Conservation,' Endangered Wildlife, Vol. 11, 1992, pp. 10-15.

[22] T. S. Simelane and G. I. H. Kerley, "Recognition of Reptiles by Xhosa and Zulu Communities in South Africa, With Notes on Traditional Beliefs and Uses,"African Journal of Herpetology, Vol. 41, 1997, pp. 49-53. doi:10.1080/21564574.1997.9649975

[23] J. G. Castley and G. I. H. Kerley, "The Paradox of Forest Conservation in South Africa," Forest Ecology and Management, Vol. 85, 1996, pp. 35-46. doi:10.1016/S0378-1127(96)03748-6

[24] C. Fabricius and M. Burger, "Comparison between a nature reserve and adjacent communal land in Xeric Succulent Thicket - an Indigenous Plant User's Perspective," South African Journal of Science, Vol. 93, 1997, pp. 259-262.

[25] C. A. Peres, "Effects of Hunting on Western Amazonian Primate Communities," Biological Conservation, Vol. 5, 1990, pp. 47-59. doi:10.1016/0006-3207(90)90041-M

[26] E. Bowen-Jones and S. Pendry, "The Treat of Primates and Other Mammals from the Bushmeat Trade in Africa, and How this Threat could be Diminished," Oryx, Vol. 33, No. 3, 1999, pp. 233-246.

[27] A. Rosser, N. Ash and M. Sorola, "Approaches to the conservation of species used in traditional medicines," South African Journal of Medicine, Vol. 48, 2000, pp. 1688-1690.

[28] F. Berkes, J. Colding and C. Folke, "Rediscovery of Traditional Ecological Knowledge as Adaptive Management," Ecological Applications, Vol. 10, No. 5, 2000, pp. 1251-1262. doi:10.1890/1051-0761(2000)010[1251:ROTEKA]2.0.CO;2

[29] M. Richards, "Protected Areas, People and Incentives in Search for Sustainable Forest Conservation in Honduras," Economic Conservation Vol. 23, No. 3, 1996, pp. 207-217.

[30] W. R. Siegfried, "Preservation of Species in Southern African Nature Reserves," B. J. Huntley, “Biotic Diversity in Southern Africa-concepts and Conservation," Oxford University Press, New York. 1989.

[31] B. E. Van Wyk, C. M. Van Wyk and P. Novellie, "Flora of the Zuurberg National Park. An annotated Checklist of Ferns and Seed Plants," Bothalia, Vol. 18, 1988, pp. 221-232.

[32] D. Tilman, "Biodiversity: Population versus ecosystem stability," Ecology, Vol. 77, No. 2, 1996, pp. 350-363. doi:10.2307/2265614 
[33] U. Pond, B. B. Beesley, L R. Brown and H. Bezuidenhout, "Floristic Analysis of the Zebra National Park, Eastern Cape," Koedoe, Vol. 45, No. 1, 2002, pp. 335-357.

[34] J. Botha, E. T. F Witkowski and C. M. Shackleton, "An inventory of medical plants traded on the western boundary of the Kruger National Park, South Africa," Koedoe, Vol. 44, No. 2, 2001, pp. 7-46.

[35] R. Liversidge, "The Birds of the Addo Elephant National Park," Koedoe, Vol. 8, 1965, pp. 41-67.

[36] B. R. Roberts, "The Vegetation of the Golden Gate Highlands National Park," Koedoe, Vol. 12, 1969, pp. 15-28.

[37] M. F. Bates, “A Provisional Checklist of Reptiles and Amphibians of the Golden Gate Highlands National Park," Koedoe, Vol. 34, No. 2, 1991, pp. 153-155.

[38] K. A. Earlè and A. B. Lawson, "An Annotated Checklist of the Birds of The Golden Gate Highlands National Park," Koedoe, Vol. 31, 1988, pp. 227-244.

[39] H. Bezuidenhout, "An Ecological Study of the Major Vegetation of the Vaalbos National Park, Northern Cape - The Than Droogeveld section," Koedoe, Vol. 37, No. 2, 1994. pp. 19-41.

[40] H. Bezuidenhout, "An Ecological Study of the Major Vegetation of the Vaalbos National Park Northern Cape - The Than Graspan-Holpan section," Koedoe, Vol. 338, No. 2, 1995, pp. 65-83.

[41] C. F. Johnson, R. M. Cowling and P. B. Phillipson, "The Flora of the Addo National Park, South Africa: Are Threatened Species Vulnerable to Elephant Management," Biodiversity and Conservation, Vol. 8, 1999, pp. 1447-1456. doi:10.1023/A:1008980120379

[42] V. L. Williams, K. Balkwill and E. T. F. Witkowski, "A Lexicon of Plants Traded on the Witwatersrand Umuthi Shops, South Africa," Bothalia, Vol. 31, 2001, pp. 71-98.

[43] P. C. Zietsman, P. J. du Preez and H. Bezuidenhout, "A Preliminary Checklist of Flowering Plants of the Vaalbos National Park," Koedoe, Vol. 42, No. 2, 1992, pp. 95-112.

[44] M. H. Knight and A. J. Hall-Martin, "Helicopter Surveys of the Addo Elephant Park," Internal Report, South African National Parks, Kimberley, March-May 1994.

[45] J. G. Castley and M. H. Knight, "Helicopter Based Survey of Addo Elephant National Park," Unpublished Internal Report, South African National Parks, Kimberley, February 1998.
[46] F. W. Fox and N. Young, "Food from the Veld," Delta, Johannesburg, 1982.

[47] E. Palmer and N. Pitman, "Trees of Southern Africa," Vol. 1, Balkema, Cape Town, 1972.

[48] A. Hutchings, A. H. Scott, G. Lewis and A. Cunningham, "Zulu Medicine Plants - An Inventory," University of Natal Press, Pietermaritzburg, 1996.

[49] F. Venter and J. Venter, "Making the Most of Indigenous Trees," Briza publication, Pretoria, 1996.

[50] B. Van Wyk and N. Gericke, "People's Plants- A Guide to Useful Plants of Southern Africa," Briza publications, Pretoria, 1999.

[51] A. B. Cunningham and A. S.Zondi, "Use of Animal Plants for Commercial Trade in Traditional Medicine," Institute of Natural Resources, Rep. 76, pp. 1991, 1-40.

[52] A. B. Cunningham and A. S. Zondi, "Striped Weasel: Traditional Medicine and Conservation," Endangered Wildlife, Vol.11, 1992, pp. 10-15.

[53] J. Bryom, "Field guide to the Game of the Natal and Zululand," Sealandair, Durban, 1977.

[54] H. Ngubane, "Body and Mind in Zulu medicine: An Ethnology of Health and Diseases in Nyuswa-Zulu Thought and Practice," Academic Press, London, 1977.

[55] T. S. Simelane, "The Traditional Use of Indigenous Vertebrates," MSc dissertation, University of Port Elizabeth, Port Elizabeth, 1996.

[56] W. R. Branch, "South African Red Data Book: Reptiles and amphibians," South African Scientific programme, Report 151, 1988, pp. 1-24.

[57] C. Hilton-Taylor; O. A. Leistner and B. A. Momberg, "Red Data List of Southern African Plants (Strelitzia)," National Botanical Institute, 1996.

[58] K. N. Barnes, "The Eskom Red Data Book of Birds in South Africa, Lesotho and Swaziland," Birdlife South Africa, Johannesburg, 2000.

[59] J. H. Zar, "Biostatistical Analysis," 2nd edition, Pentice Hall, New Jersey, 1984.

[60] J. O. Kokwaro, "Medical Plants of East Africa," East African Literature Bureau, Nairobi, 1983.

[61] A. T. Bryant, "Zulu Medicine and Medicine-Men," C. Struik, Cape Town, 1966.

[62] B. Akendengue, "Medical Plants Used by Fang Traditional Healers in Equatorial Guinea," Journal of Ethnopharmacolog, Vol. 37, 1992, pp. 165-173. doi:10.1016/0378-8741(92)90075-3

[63] O. L. B. Phillips and A. H. Gentry, "The Useful Plants of Tambota, Peru I: Statistical Hypothesis 
Tests with a New Quantitative Technique," Economic Botany, Vol. 47, 1993, pp. 15-32. doi:10.1007/BF02862203

[64] H. N. Balyamujura and H. G. van Schalkwyk, "Nature Conservation Versus Human Needs: The Case of Manyeleti Game Reserve," Agrekon, Vol. 38, 1999, pp. 861-873. doi: $10.1080 / 03031853.1999 .9524895$

[65] C. M. Shackleton, "Demography and Dynamics of Dominant Woody Species in a Communal and Protected Area of the Transvaal Lowveld," South African Journal of Botany, Vol. 59, 1993, pp. 569-574.

[66] D. W. Schemske, B. C. Husband, M. H. Ruckelshans, C. Goodwill, I. N. Parker and J. G. Bishop, "Evaluating Approaches to the Conservation of Rare and Endangered Plants," Ecology, Vol. 75, 1994, pp. 584-606. doi:10.2307/1941718

[67] V. H. Heywood, "Global Biodiversity Assessment," Cambridge University Press, New York, 1995.

[68] C. M. Shackleton, "Comparison of the Plant Diversity in Protected and Communal Lands in the Bushbuckridge Lowveld Savanna, South Africa," Biological Conservation, Vol. 94, 2000, pp. 273-280. doi:10.1016/S0006-3207(00)00001-X

[69] T. M. Caro, "Species Richness and Abundance of Small Mammal inside and Outside African National Park," Biological Conservation, Vol. 98, 2001, pp. 251-257. doi:10.1016/S0006-3207(00)00105-1

[70] H. Else and J. du P. Bothma, "Developing Partnerships in a Paradigm to Achieve Conservation Reality in South Africa," Koedoe, Vol. 43, No. 1, 2000, pp. 19-26.

[71] B. M. Sibanda and A. K. Omwega, "Some reflections on conservation, sustainable development and equitable sharing of benefits from wildlife in Africa: the case of Kenya and Zimbabwe," South African Wildlife Research, Vol. 26, No. 4, 1996, pp. 175-181.

[72] C. Quiroz, "Indigenous Knowledge and Development," Monitor, Vol. 6, No. 2, 1998, pp. 1-3.
[73] G. D. La Cock and J. H. Briers, "Bark Collecting at Tootabie Nature Reserve, Eastern Cape, South Africa," South African Journal of Botany, Vol. 58, 1992, pp. 505-509.

[74] A. B. Cunningham, "People, park and plant use. Recommendations for Multiple Use Zones and Development, Alternatives around Bwindi Impenetrable National Park of Uganda," People \& Plants working paper 4, UNESCO, Paris, 1996.

[75] J. A. Richardson, "Wildlife Utilization and Biodiversity Conservation in Namibia: Conflicting Objectives?" Biodiversity and Conservation, Vol. 7, 1998, pp. 549-559. doi:10.1023/A:1008883813644

[76] J. H. Haynes, "Involving Communities in Managing Protected Areas: Contrasting Initiatives in Nepal and Britain," Parks, Vol. 8, 1998, pp. 54-61.

[77] C. Fabricius and M. Burger, "Comparison between a Nature Reserve and Adjacent Communal Land in Xeric Succulent Thicket - An Indigenous Plant User's Perspective," South African Journal of Science, Vol. 93, 1997, pp. 259-262.

[78] G. I. H. Kerley, R. L. P. Pressey, R. M. Cowling, A. F. Boshoff and R. Simms-Castley, "Options for the Conservation of the Large and Medium-Sized Mammals in the Cape Floristic Hotspot, South Africa," Biological Conservation, Vol. 112, 2002, pp. 196-190.

[79] B. M. Sibanda and A. K. Omwega, "Some Reflections on Conservation, Sustainable Development And Equitable Sharing of Benefits from Wildlife in Africa: The Case of Kenya And Zimbabwe," South African Wildlife Research, Vol. 26, No. 4, 1996, pp. 175-181.

[80] D. Hanekom and L. Liebenberg, "Utilization of National Parks With Special Reference to the Costs and Benefits to Communities," Bulletin of Grassland Society of South Africa, Vol. 5, 1994, pp. 25-36.

[81] M. Richards, "Protected Areas, People and Incentives in Search for Sustainable Forest Conservation in Honduras," Economic Conservation, Vol. 23, No. 3, 1996, pp. 207-217. 